\title{
ACRL in Chicago
}

\section{Highlights of ACRL programs at the ALA Annual Conference}

$\mathrm{T}$ he Windy City was alternately rainy and sunny but always humid for attendees of ALA's 119th Annual Conference, held July $6-12,2000$. Total conference attendance was 24,913 members, exhibitors, exhibits only, and guests, including 11,830 paid registrants $\boldsymbol{E} \boldsymbol{d}$. note: Thanks to the ACRL members who summarized programs to make this report possible.

\section{ACRL in the 21st century}

ACRL President Larry Hardesty stated that a year with three zeros in it demanded that we reflect on where we have been and what is ahead for librarians. The ACRL President's Program, "Celebrating Our Sticcesses, Confronting Our Challenges: ACRL Enters the 21 ${ }^{\text {st }}$ Century," presented a thought-provoking look both backward and forward.

Evan Farber (emeritus librarian, Earlham College) introduced his presentation with a humorous parody of Mel Brooks as the 2,000 Year Old Librarian, disputing fines from the Alexandrian Library and recounting chats with "Joe" Gutenberg and Melville Dewey.

Citing historical literature, Farber discussed the changed perception of academic librarians in the teaching/learning process. He outlined the transition from a supportive to an enhancing, and, finally, to an instructional role.

In the enhancing role, librarians were "unobtrusive and diffident." The instructional role has moved along more quickly because of information technology "creating new partnerships between librarians, students, and faculty." Farber ended by saying that "technology has not taken over, but has enhanced the role of librarians."
Providing a view of challenges librarians face, Carla Stoffle (University of Arizona) emphasized that we must take charge to create the future we want in higher education. Stoffle recommends leveraging our resources, reinventing ourselves, becoming activists, and gaining at least some control over the network. She referred to the "Keystone Principles"1 and called upon us "to do better and be better than we are now."

Some examples of challenges Stoffle mentioned are the difficulty in recruiting, the need to work on diversity in the profession, and the need to give up sacred cows (i.e., faceto-face reference and outmoded conceptions of physical space allocations in the library). She concluded by paraphrasing two of Jerry Campbell's axioms: "New windows of opportunity will open" and "New windows of opportunity are short-lived."

Emily Mobley (Purdue University) added her perspective to many of the issues discussed by Stoffle as she talked about the future. Mobley stated that "change will occur more rapidly than before" and that "the future is being shaped by what is occurring today, outside of libraries." She divided the areas that contribute to our future into five sections: politics, sociology/culture, economics/business, technology, and education.

Growing conservatism, changing mores of philanthropy, the e-business presence, mergers in information industry companies, intellectual property rights versus free access, and the demand for accountability were a few of her examples of the forces libraries must face. She urged the audience to collaborate (form "collaboratories"), to follow trends, look out- 
side libraries, and "prepare for the future rather than be blinclsided by it."

Mobley was upbeat when she said, "Librarianship will be alive, but must continue to undergo significant change in order to stay well."

Rick Ekman (Atlantic Philanthropic Service Co.) responded with the higher education perspective. He pointed to the shortage of subject specialist librarians and questioned whether library schools have lost important course aspects in their shift to adapt to training for the electronic age. He wondered about collaboration, archiving, and the need for duplicate and overlapping collections.

How big is big enough? He stated that the new stereotype of librarians is that they like all the electronic bells and whistles too much. Meanwhile, students' research skills have atrophied in this new environment and faculty and librarians need to work to improve them.

The question-and-answer period was lively, with panel members and the audience questioning the speakers about disinterme-diation and the library's investment in research and development. The general feeling was that librarians and libraries face challenges, but as long as the profession stays alert and takes an active role we can help create the future-Jamie Hastreiter, Eckerd college, hastreja@eckerd.edu

\section{Cooperative research in sociology and anthropology}

Four speakers in this session spoke to various aspects of the topic "Sociological and Anthropological Research in Transition: Trans-disciplinary Collaboration and Qualitative/Quantitative Rapprochement," sponsored by ACRL's AntJropology and Sociology Section.

William J. Wheeler (Yale University) provided an overview, suggesting that the increasing use of data, especially data enabled by Web interfaces, is at least one of the factors contributing to changes in social science research. Data are infinitely interpretable and have lives far beyond their original gathering parameters or historical period.
Tom Smith (National Opinion Research Center) provided information on the International Social Survey Programme, a crossnational collaboration on social science topics he helped found. ${ }^{2}$ He answered many questions, including one that illuminated the linguistic and cultural sensitivity of the Programme's researcher in constructing valid crosscultural survey questions.

Jennifer Hiselman (Illinois Criminal Justice Information Authority) ${ }^{3}$ presented information on state-level criminal justice statistics. She provided various drawbacks to using the data, but also argued it should be

Larry Hardesty, Scottie Cochrane, Evan Farber, Carla Stoffle, Richard Ekman, and Emily Mobley reviewed successes and challenges at the ACRL President's Program.

more heavily used. She recommended a cen tral site that links to state statistical analysis centers. ${ }^{4}$

The two Yale librarians ended the program with examples of interdisciplinary research and the expansion of data services. Wheeler provided examples of current interdisciplinary research and data use at Yale; and Jocelyn Tipton noted the increasing necessity for librarians to have data literacy in guiding researchers to relevant sources. She recommended librarians consider the Association of Public Data User' and the International Association for Social Science Information Service \& Technology ${ }^{\prime}$.- William J. Wheeler, Yale University Social Science Libraries and Information Services, william wheeler@yale.edu

\section{Challenges for ethnic collections}

In the African American Studies Librarian's (AFAS) program, "Future Challenges for Ethnic and Cultural Academic Collections," four speakers working closely with collections of Native American, African American, Asian, 
and Chicano materials discussed issues integral to ethnic collections.

In response to the question "What role should ethnic academic collections play in the future?" all panelists agreed preservation and access are critical goals.

Whether ethnic collections should be segregated or integrated was also debated. Lisa Pillow (Ohio State University Black Studies Library) stated that the decision depends on the collection and institution. One of the advantages to separate collections is the convenience of having materials located together But the disadvantage is that maintaining separate collections is more expensive because it requires subject specialists and more space.

In regard to defining core collections for ethnic and cultural collections, John Barry (Oklahoma State University) advocated a collection policy that allows one to collect as much as possible, including material written by everyday people. Although most panelists agreed that core collections can be de fined, all stressed the importance of constant searching for materials not produced by traditional publishers.

Ling Hwey Jeng (School of Library \& Information Science, University of Kentucky) raised questions about defining Asian collections. For example, there are materials produced in the United States about Asian Americans, but where should those materials be housed?

Lillian Castillo-Speed (University of California at Berkeley Ethnic Studies Library) elaborated on the need to recruit librarians to head ethnic studies libraries. Finally, all panelists agreed with Castillo-Speed's statement: "The goal is survival."-Elaine $L$. Westbrooks, University of Pittsburgh, elwst2@ pitt.edu

\section{Visual/media literacy}

The ARTS Section sponsored a program entitled "Is Seeing Understanding? Approaches to Visual/Media Literacy in an Information Age." The panel provided cohesive papers that ranged from describing user-ended methodology and interpretation of visual material, as well as issues of incorporating new media. Moderated by Floyd Zula, this well attended program featured speakers Paula Murphy (Chicago Historical Society) and Sally Mason-Robinson (National Video Resources in Chicago).

Murphy, an ARTS Section member, provided the audience with an apt survey of the

\section{Annual Conference audiocassettes available}

Audiocassettes of selected ACRL programs from the 2000 ALA Annual Conference in Chicago are now available. Each program consists of two cassettes, $\$ 26$, unless otherwise noted.

New Trends in Accreditation/Distance Learning Programs. Order no. ALA 007

Byting into Video: DVD and Networked Delivery. Order no. ALA 013

20/20 Vision for the Future. Order no. ALA 015

The Digital Millennium Copyright Act: Responding to the Requirements of the Act. Order no. ALA 021

Applying the New Standards for College Libraries. Order no. ALA 026

Instruction for First-Year Students. Order no. ALA 030

Artifacts in Libraries: The Intersection of Library and Museum Practice in
Rare Book and Manuscript Repositories, 3 cassettes, \$39. Order no. ALA 033

New Communication and Information Models for the New Millennium, 3 cassettes, \$39. Order no. ALA 036

Intellectual Freedom Principles for Academic Libraries: An Illustrated Tour, 1 cassette, \$13. Order no. ALA 040

Sharing Strategies for Achieving Diversity. Order no. ALA 043

Celebrating Our Successes, Confronting Our Challenges. Order no. ALA 050

Audiocassettes for other ALA programs are also available. Call, write, or fax your order to Teach 'em, 160 E. Illinois St., Suite 300, Chicago, IL 60611; (800) 225-3775; fax: (312) 467-9271, credit cards only; e-mail: teachem@bonus-books.com. You may pay by check (payable to Teach 'em) or credit card (VISA, MC, AMEX, Diners Club). 
Chicago Historical Society's Research Center. The user population includes architects, business people, and genealogists, in addition to students and scholars.

Murphy discussed the many ways in which the staff assist these users with their research and how visual literacy plays a key role in the interpretation and analysis of the material from the researcher's viewpoint and also from the librarian's perspective.

Because there are many types of users, key visual literacy issues to consider are the research goal of the user and the location of the user (onsite or remote).

Murphy also demonstrated the digital/virtual collection via the Chicago Historical Society's Web site. ${ }^{7}$ The richness of the collection, as exemplified by samples shown such as that of the Great Chicago Fire, magnify the value of visual and ephemeral materials.

Sally Mason-Robinson elucidated her role as a public librarian, and described the transition of adding and incorporating visual media in her institution. Mason-Robinson stated that despite the growing popularity of video material in an age where special effects and "reality TV" dominate the airwaves, the public was still

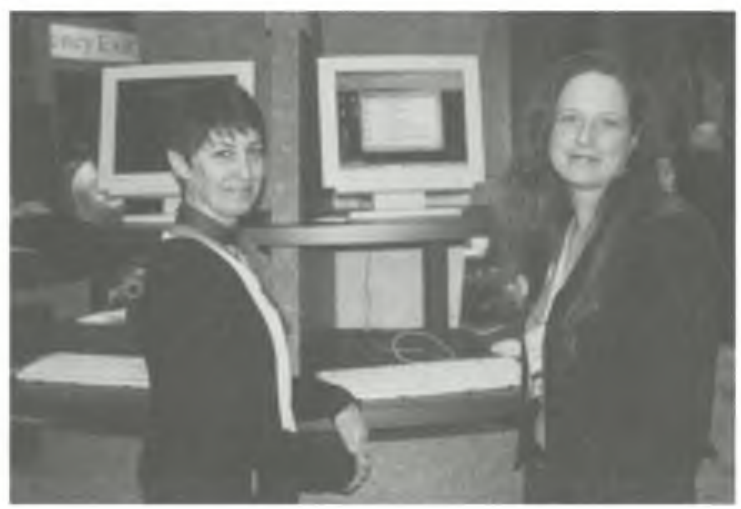

Geri Ingram Bunker (left) takes time to visit with an exhibitor. deprived of a video collection. The user population had made her aware of the importance of visual material in the library, yet, odclly enough, a proposal for grant funding to begin a video collection was continually denied.

Why? Mason-Robinson hypothesized that a resistance to video media as a legitimate means of learning as a significant factor. In addition, she said there was "a strong need to hang onto print," in general.

Given the wealth of visual material available, as presented by the remaining panelists, Mason-Robinson in closing summarized that those librarians in the position of seeing the impact that the visual media can make "must make converts" in order to promote visual literacy.-Nadine M. Flores, Los Angeles Public Library, n_flores735@botmail.com

\section{Applying the new "Standards for college libraries"}

Will Bridegam (Amherst College) introduced the rationale for developing ACRL's new "Standards for college libraries," ${ }^{\prime 8}$ including the interest in outcomes assessment in addition to inputs and outputs. Dave Pilachowski (Williams College) described the historical evolution of the new standards. He explained the need for placing quantitative numbers in context and how these standards produce more credible support of library goals.

After this brief introduction, panel members demonstrated each of the necessary steps in applying the standards. Sharon McCaslin (Longwood College) explained the importance of articulating the library mission statement, providing examples of the essential in- gredients. Richard Hart (Pennsylvania State University, Erie) described the process of selecting both aspirational and literal peer groups, reporting the results of a survey he had conducted among northeastern libraries. James Mullins (Villanova University) demonstrated how the data gathered can provide meaningful statistics. He showed how the points of comparison ratios are used, briefly displaying and explaining regression analysis to compare data. Bonnie Gratch Lindauer (City College of San Francisco) discussed outcomes assessment and measures of performance.

After the preparatory data has been gathered, the next steps are to evaluate the library and produce a report on the analysis The next panelist, Rebecca Bostian (Governors State University) presented her experience in applying the standards and reporting the outcome. Then Bill Nelson (Augusta State University) and Bob Fernekes (University of South Carolina, Aiken) demonstrated how 
several sections of the standards correspond to requirements from different regional accrediting bodies

While most of the audience seemed pleased with the new direction of the standards, some concern for the lack of explicit uniform numbers was expressed. The panelists emphasized that the standards are intended to be flexible and open-ended so that creative and new statistics can be developed and applied to completely new services and collections. - Sharon McCaslin, Longwood College, smccusli@longuood.lux.edu

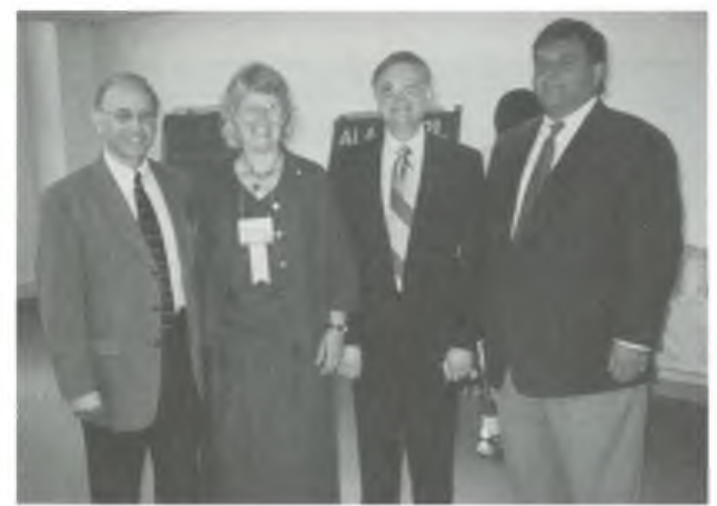

Chairs of the Distance Learning Section past and present (left to right)-Barton Lessin (1991-92), Carol Moulden (2000-01), Harvey Gover (1999-00), Tom Abbott (199697) - gathered to celebrate the 10th anniversary of DLS. ways of assessing quality and effectiveness. As Posey saicl, "The process never stops. It's a way of operating."

O'Gorman emphasized the importance of being involved in the campus assessment efforts when she said, "Being part of the quality movement at Cincinnati State has paid off for the library by allowing us to add an instructional lab and to redesign our help desk and public services area."

Some methods of self-assessment include using pre-existing standards and guidelines to analyze organizational performance. The ACRL Guidelines and AQIP place a large focus on student learning and assessment.

Bernie Sloan (University of Illinois) paraphrased the principles behind the ACRL "Guidelines for Distance Learning Library Services." Sloan foresees a blurring of responsibility for various distance learning services and a trend toward more collaborative or centralized programming.

All six regional accrediting agencies are in the process of revamping their standards, accorcling to Oswald Ratteray (Middle States Commission on Higher Education). The assessment movement is influencing all aspects of the new standards. In respect to libraries, there is a debate over the level of specificity to attribute to the physical library

He noted that non-lilsarian policy-makers question whether every institution needs its own physical library and what the role of consortia is in relation to this. Ratteray advocated a shared responsibility berween faculty and librarians for information literacy.-Nicole Camphell, Washington State Iniversity Vancouver, campbell@ vancouverusuedu, and Marcia Suter, Lniversityof Toledo,msuter@utnet.utoledo.edu

\section{Collecting contemporary fiction}

Why should academic libraries buy contemporary fiction? What distinctions should they make between literary and genre fiction? How much fiction is enough in any academic collection? What will the needs of literary scholars be in 20 years? Does Danielle Steel belong in a college or university library?

These and similar concerns were addressed by ACRL's newly renamed Literatures 
in English Section (formerly English and American Literature Section) during its "Collecting Contemporary Fiction for the New Millennium" program.

Deborah Jakubs (Duke University) pointed out that fiction is becoming increasingly important as more teaching and research become interdisciplinary and experimental. It is a primary source in cultural studies because it describes the details of everyday life. The more publicity fiction receives, according to Bob Nardini (Yankee Book Peddler) the more likely libraries will purchase it. His customers are twice as likely to buy novels reviewed in a New York Times book review.

Nancy Kushigian (University of California, Davis) described her library's approach, which includes buying everything in certain areas, such as Caribbean fiction in English, and collaborating with librarians in related fields such as Gender Studies. She emphasized the need to convince administrators that fiction is essential to research collections. Novelist Julia Alvarez (author most recently of In the Name of Salome) explained how she selects books for her personal library. She said that the quirky individual tastes of librarians and faculty are essential to giving collections distinctive personalities.

The program was followed by an open reception, and a book-signing by Alvarez.Michael Adams, City University of New York, madams@gc.cuny.edu

\section{Partnerships that produce}

The Chicago Historical Society (CHS) graciously hosted this year's Education and Behavioral Sciences Section (EBSS) program. CHS is a privately endowed, independent institution devoted to collecting, interpreting, and presenting the rich multicultural history of Chicago and Illinois, as well as selected areas of American History to the public through exhibitions, programs, research collections, and publications.

Russell L. Lewis Jr. (CHS's acting co-president and Andrew W. Mellon director for Collections and Research) began the "Collaborative Cool: Partnerships that Produce" program with an overview of CHS's voluminous and varied holdings, describing its changing missions and acquisition policies over the years.
Lewis described the considerable satisfaction (and occasional disappointment) associated with several recent collaborative projects, including the "Great Chicago Fire" (a particular hit with tremendous Web site use), "Just the Artifacts," and the "Encyclopedia of Chicago History," being produced in collaboration with the Newberry Library. Collaborations, Lewis noted, have "a transforming effect" and CHS looks forward to new partnerships.

Nancy Buenger, Costume and Textile conservator and chief creator of CHS's "Wet With Blood" project and Web site ${ }^{10}$, followed with a lively account of the CHS's investigation of Abraham Lincoln relics. She noted the successful convergence of different media in this project, which has attracted PBS interest.

The program also provided ElBSS with an opportunity to present its annual "Distinguished Librarian Award" to this year's winner, Leslie Bjorncrantz (Northwestern University).-Ellen D. Gilbert, Rutgers University, egilbert@rci.rutgers.edu

\section{Instruction for First-Year Students}

The Instruction Section presented "Instruction for First-Year Students." Randy Hensley (University of Hawaii at Manoa) served as moderator and opened the program with "Introduction and Characteristics of First-Year Students," providing a "snapshot" of current first-year students in colleges.

Hensley painted a picture of the year 1982, when most of these first-year students were born, bringing to light that these students have grown up with personal computers, cellular phones, and more. He asserted that they do not necessarily have short attention spans, but that they process information rapidly, they are "change ready," affiliative, and "technology comfortable."

Frances Jacobson (University Laboratory High School, University of Illinois at UrbanaChampaign), with her "Ready or Not-Here They Come" presentation, gave a perspective on what high-school students, who will soon be first-year college students, are currently experiencing in regards to bibliographic instruction, Internet training, information literacy standards, and more.

Students come to college having had varying levels of support, varying existence of stan- 
dards, and varying approaches to $K-12$ teaching. Jacobson incorporated an active learning exercise to demonstrate that first-year students need more "participatory" instruction.

Margit Misangyi Watts (Rainbow Advantage/Freshman Seminar Programs, University of Hawaii at Manoa) spoke on "Freshmen Narratives," and asserted that we need to view "information literacy as narrative" and be more receptive to our students' "stories." She used examples of current freshmen-oriented programs, such as learning communities, freshmen seminars, College 101 courses, and thematic workshops. ${ }^{11}$ - Brittney Goodman, Minnesota State University, Moorbead, goodmanb@ mnstate.edu

\section{The library of the future}

The University Libraries Section (ULS) and the College Libraries Section (CLS) co-spon- sored "20/20 Vision for the Future," a lively program attended by more than 500 people.

John Lombardi (TheCenter for Studies in the Humanities and Sciences, University of Florida) provided an energetic and pointed talk on the future of academic libraries. Using examples from his teaching experience, Lombardi demonstrated that students feel our hierarchical notions of organized information and the importance of the physical building are antiquated, the book as a physical object "quaint."

He cited the changing role of the librarian as gatekeeper, as well-with the digital landscape within everyone's reach, we are able to be our own gatekeepers. The cost relationships inherent in disseminating information have changed for good. Traditional library strengths can fit into this new environment and Lombardi believes we will eventu-

\section{News from the University Libraries Section}

Ed. note: For a report on the ULS program, please see "The library of the future" above.

\section{Welcome to the 2000-01 academic year}

It is a pleasure to report that the University Libraries Section (ULS) is off to a very good start, following the outstanding leadership of James Estrada over the past year and the stellar program on the future of academic libraries at the ALA Annual Conference. If you weren't there, you missed a good one.

We had very creative and productive meetings of the Executive Committee and our section committees at the ALA Annual Conference. Collectively, we are brimming with ideas to enhance the stature of university libraries and librarians on our campuses, improve communication with ULS members through a new electronic list and membership brochure, and provide continuing education for our members through our Annual Conference Program and the discussion group meetings at the Midwinter Meeting.

Through the course of the fall, you will be hearing from our committee chairs regarding their plans for programs and projects. If you have suggestions for the ULS Executive Committee, or any of our com- mittees, or want to become more involved in the work of ULS, please feel free to contact me. I look forward to working with you over the year ahead.-Elaine K. Didier. Oakland University, didier@oakland.edu.

\section{Executive committee}

The ACRL/ULS Executive Committee met twice during the ALA Annual Conference to review and discuss the ULS strategic directions and the LLS plan for implementing the goals of the recently published ACRI. Strategic Plan 2005 (CERL News, May 2000).

Possibilities for future initiatives include cxpanded conference program sponsorship, member interest surveys, and greater collaboration with other ACRL sections and the ALA public relations campaigns. Upcoming programs will include the Current Topics Discussion Group on the electronic environment at the Midwinter Meeting in Washington, D.C. in 2001, and an Annual Conference 2001 program entitled, "Seeing Ourselves As Others See Us: How Others Assess What Libraries Do."

\section{Heads of Public Services}

The ACRL/ULS Heads of Public Services meeting, chaired by Faye Backie, met with 
ally define strengths in various ways with, for example, the projects for a "mega" library union catalog, digitizing our unique special collections, and translating our information utilities into library portals to compete against commercial services.

Lombardi predicted that librarians would maintain and manage their unique collections, buy fewer materials overall, and assist patrons in evaluating the information in our increasingly digiral world.

In summary, Lombardi offered his "Rules for Digital Survival," including "the objects are not as important as the content," "helping clients find resources in a digitally chaotic world is the first priority," ". . . join consortia and urge others to take the lead," and "for the next ten years, if it works well, is reliable, and you know how to use it, it is obsolete."12

(continued from previous page)

a packed agenda. Mary Jackson (Associations of Research Libraries) updated the group on the North American Interlibrary Loan and Document Delivery project and on draft circulation standards. The circulation standards will address self-service check out, facilitate communication between different circulation systems, and help with access to electronic resources.

Next, the group discussed public service organizational structures. Jeanne Boyle (Rutgers University) and Brenda Johnson (University of Michigan) shared their organizational charts and initiated comments on organizational flexibility and team cultures. Other issues raised included organizing for efficient use of staff time, sharing staff with other divisions, and placing new initiatives and services.

Martha Kyrillidou (ARL) discussed the ARL New Measures Initiative (formerly the SERVQUAL pilot), which is currently seeking funding to expand to a three-year period. Information is on the Web at http:// www arl.org/stats/newmeas/newmeas. html.

Twelve libraries participated in the in tial new measures pilot project, which grew out of a push for more accountability and resource-use maximization among research
The respondents did not rebut Lombardi's ideas, but added and expanded on them. Jerry Campbell (University of Southern California) discussed the pace of change and the inadequate infrastructure we face in libraries.

He theorized that the biggest changes would come about with the business world's discovery of the financial opportunities in education and our challenges to adjust and change to reflect new business models.

Carol Ann Hughes (Questia Media) agreed that business plans will be increasingly important and that we have to face changes as "real people with real money." She envisions higher education and academic libraries in 2020 in "start-up mode" with the need to become, quoting Karl Weick, "garrulous." Libraries can do this by talking, arguing, and taking risks.

libraries. The data gathered in the pilot is just now being analyzed. It is hoped that this initiative will provide both data of local relevance and of use for benchmarking.

Diane Kresh and Linda Arret (Library of Congress) were on hand to report on the Library of Congress-led Collaborative Digital Reference Service (CDRS). The pilot is up and running with 17 participating libraries. This Web-based reference service uses request manager software to disperse reference queries based on user-stated needs and participating institution service profiles. Further information on this important project is available at http://www.loc.gov/rr/ digiref/.

Finally, the group discussed revising library Web sites, including issues of process, design and organization, and post-revision. Participants agreed this is an ongoing struggle and it is often challenging to move beyond the planning stages. Ideas for early usability testing, development of a sense of place, service delivery parallels, and integrating new technologies were discussed.

The group will meet again at Midwinter, led by incoming chair Lucinda Covert-Vail (New York University)._Jennifer Elans, University of Washington, jrevans@u. washington.edu 
Micheline Jedrey (Wellesley College) focused on how we can build on our core competencies, without defining ourselves too narrowly. We need to look for the expansive definitions within our profession and our jobs, allowing for flexibility and resiliency for adaptability.

The program reflected the fast-paced digital realities we all face now and was a thoughtprovoking look at our not-so-distant future.Jennifer Evans, University of Washington, jrevans@u.washington.edu

\section{Women's Studies in the Year 2000}

Preceded by the presentation of two new awards, one for Significant Achievement to Lynn Westbrook and one for Career Achievement to Susan Searing, the Women's Studies Section program-"Taking the Temperature of Women's Studies in the Year 2000" - gave participants a chance to share their insights and ideas about the state of Women's Studies librarianship.

Ellen Broidy (University of California, Irvine) put forward questions concerning changes in the disciplines that make up Women's Studies; Sarah Pritchard (University of California, Santa Barbara) related issues that clealt with the institutional location of Women's Studies; Sancly River (Texas Tech University) introduced topics dealing with electronic resources; and Dolores Fidishun (Penn State University) focused on advances in education and instruction. Group discussions produced the following points which will be used to guicle programming and other initiatives of the section:

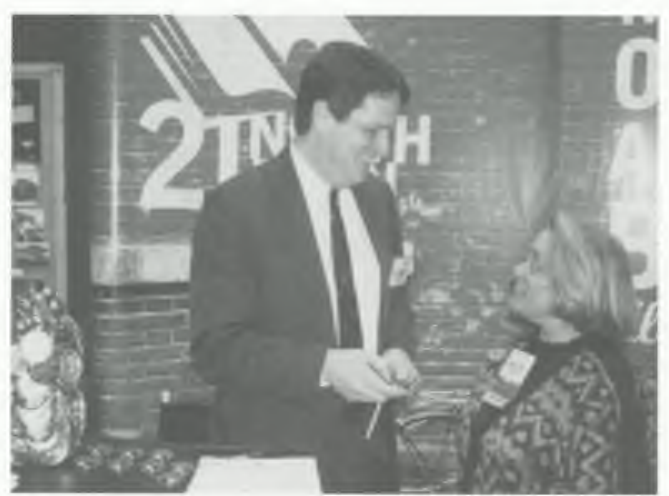

Barbara Ford, a past president of ACRL and ALA, visits with the 21 North Main representative at the exhibits.
Location of Women's Studies: working with selectors in other fields; managing approval plans; collection development issues at small colleges; and selection of foreign language materials.

Changes in the discipline: effects on selectors of the distinction between feminist theory and Women's Studies; political effects of how we define the discipline; the shift in emphasis of Women's Studies discourse; and Women's Studies versus Gender Studies.

Electronic resources: getting patrons to use electronic resources; patrons' recognition that resources come from the library; methods of acquisition of electronic resources; trial uses of the resources; and search strategies for various resources.

Education and instruction: liaison with Women's Studies programs in transition; use of gender-friendly instruction; library instruction for off-campus and distance education students; and online reference services.Dolores Fidishun, Pennsyluania State Great Valley Scbool of Graduate Professional Studies, dxf19@psu.edu

\section{Strategies for achieving diversity}

A multicultural panel of five diversity experts offered a lively discussion incorporating strategies from different perspectives in the program "Sharing Strategies for Achieving Diversity," sponsored by the ACRL Racial and Ethnic Diversity Committee.

DeEtta Jones presented information on how the Association of Research Libraries (ARL) is recruiting, mentoring, and helping promote people of color within ARL librar- 
ies. Some of the programs include, Institute to Recruit a Diverse Workforce, Leadership and Career Development, and the University of Minnesota Training Institute. To find out more about these initiatives, consult the ARL Diversity Site at http://www.arl.org/diversity/.

Camlia Alire (Colorado State University) showcased a wonderful project she has been working on called "New Beginnings," which helps incoming junior minority faculty become more familiar with the campus, employment opportunities, and the tenure process. Alire stresses that most minority junior faculty leave because they do not get enough support from the campus and the community.

Stanton F. Biddle
(Baruch College)
showed us how
some libraries can
really accomplish di-
versity. At his li-
brary, nearly $50 \%$ of
the librarians are
people of color and
this is equally dis-
tributed among the
ranks between jun-
ior and senior faculty. He recom-

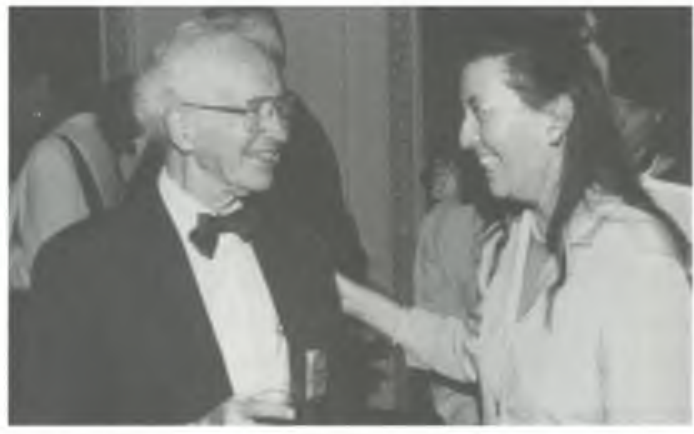

Evan Farber congratulates Academic/Research Librarian of the Year, Sharon A. Hogan.

\section{The Digital Millennium Copyright Act}

This well-attended program, sponsored by ACRL's Copyright Committee, featured four speakers who approached the topic from the following perspectives: legal facets, balanced model of fair use and copyright holder interests, distance education, and electronic reserves.

Peg Hoon (North Carolina State 'University) reminded attendees that the Digital Millennium Copyright Act (DMCA) was the most comprehensive copyright legislation since 1976 and that technology was the impetus for its existence. She addressed the following portions of the DMCA:

- Title 1 prohibits the use of circumvention software.

- Title 2 provides "a limited safe harbor for online service providers with respect to copyrighted materials passing through, cached in, residing on or linked to pages on their systems if mended two books that deal with diversity initiatives, In Our Oun Voices and Stop Talking and Start Doing.

Janice T. Koyama (UCLA) brought us interesting statistics about the Asian/Pacific American librarian statistics and demographics. She stressed that we extend our pipeline to reach out to elementary school students and have more associations like ACRL and AASL work together to develop stronger diversity programs.

Elaine Waldstedter (Ft. Lewis College) talked about librarianship from the American Indian perspective. She spoke openly about her roots and why she stays close to her homeland and family. Waldstedter stressed that librarians need to reach out to American Indian librarians and that she is a willing resource for librarians who want to develop contacts with the American Indian Library Association.-Elaina Norlin, University of Arizona, norline@u.library.arizona. edu specific requirements and rules are met."

- Section 108 reforms of the Copyright Act, which allows libraries preservation copies of materials, including digitized copies.

Carrie Russell (ALA Washington Office) approached the DMCA from the stance that it is in the best interest of all to seek a balance of power among parties. In this arena, fair use privileges would not be denied to users and the content community would receive the amount of control that it is entitled to and no more. She stressed that user rights, vis-â-vis print information, should transfer to the digital environment. Russell's words regarding the content community were cautionary, "Watch out for their statements of fact, be wary of one-sided analysis."

Liz Kirk (Johns Hopkins University) spoke of the uphill struggle to provide the same level of educational services to distance education students under the constraints of copyright since the exemptions are much more restrictive for distance education than for tra- 
ditional classrooms. She maintained that there are good reasons that distance education has often been referred to as a "second-class education." The application of fair use and lobbying of exemptions for libraries and library users in distance education top the list of "things that need to be done."

Lorre Smith (University of Albany) focused on electronic reserve policies and issues of compliance with regard to copyright. In her presentation, Smith highlighted the variations in electronic reserve policies of several universities. Some institutions tended toward rather brief and vague policies while others carefully and clearly spelled out their guidelines. Smith urged those attendees who were providing electronic reserve services and those who are consiclering them to take a look at others' policies to assist them in devising their own. - Katby Scbwanz, Washington State University, schwanz@wsu.edu

\section{Notes}

1. "The Keystone Principles," CERL News, 61, no. 2 (2000): 103-04).

2. For the International Social Survey programme, see http://www.issp.org.
3. For the Illinois Criminal Justice Information Authority, see http://www.icjia.org.

4. For state statistical analysis centers, see http://www.jrsa.org.

5. For the Association of Public Data User, see http://www.apdu.org

6. For the International Association for Social Science Information Service and Technology, see http://datalib.library.ualberta.ca/ iassist/.

7. For the Chicago Historical Society, see www chicagohistory org.

8. "Standards for college libraries," CERL News, 61, no. 3 (2000): 175-82).

9. College Libraries Section's presentation slide show and bibliography is available at http://austinc.edu/CLS/standards.html.

10. The Chicago Historical Society's "Wet With Blood" project and Web site is at http:/ www.chicagohistory.org/wetwithblood/index),

11. PowerPoint presentations, bibliographies, and other handouts are available on the Web site at http://www libraries. rutgers.edu/is/conference/index.html.

12. The complete text of John Lombardi's speech is available on his Web site at http:// jvlone.com/DigitalLibrarian.html.

\section{*ChoiceReviews.online}

\section{It's more than just a database of reviews!}

$\star$ Access to some 70,000 reviews via the Internet

$\star$ E-mail notification of new reviews, based on individual subject interests

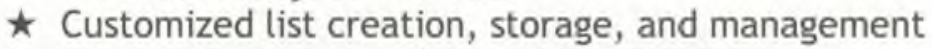

$\star$ Searchable database includes all CHOICE reviews since September 1988

$\star$ Password access allows high degree of customized use

$\star$ SUBSCRIBE NOW for $\$ 395$ ! Subscription includes 20 passwords and corresponding print issues.

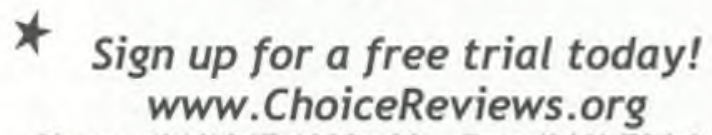




\section{A Simple Equation 1 Order +1 Low Price $=$ A World of ChE Expertise}

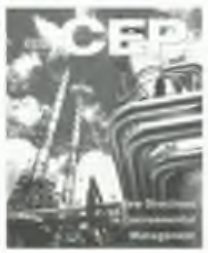

Mownobiy

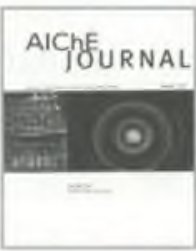

Moushth

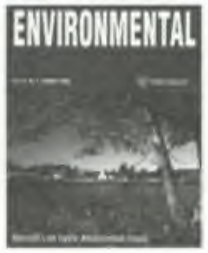

Qwartmh

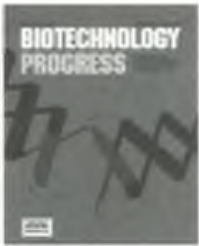

Bimoneliby-copablich

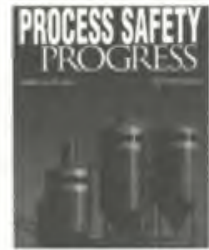

Quarterly
The AIChE Package Plan 2001 is the most cost-effective and convenient way to a complete chemical engineering collection. With just one order, you automatically receive more than 10,000 fully indexed pages, containing the year's most important research findings, news of current or pending government regulations, and industrial case histories written by practicing engineers.

The Package includes:

5 of the process industries best periodicals

1 serials volume covering safety in ammonia plants

1 annual directory of Chemical Engineering Faculty

1 industry-ready book of Equipment Testing Procedures

No gaps, reprints or duplicate coverage.

- 2000 American Institute of Chemical Engineers
Just reliable chemical engineering information.

All for just $\$ 2,075^{*}$ - a savings of more than $\$ 500$ off the regular list price.

For more information on the AIChE Package Plan 2001, call Dolly King at $212 / 591-7662$, or visit us on the Web at www.aiche.org

Be sure to ask about the online editions of our periodicals and, how, as a Package Plan Subscriber, you can save money on print/Web combinations.

- Outside North America: \$2,375 